\title{
Phosphorus cycle - possibilities for its rebuilding*
}

\author{
Katarzyna Gorazda1 ${ }^{凶}$, Zbigniew Wzorek1, Barbara Tarkoํ, Anna K. Nowak¹, Joanna Kulczycka² \\ and Anna Henclik ${ }^{3}$
}

${ }^{1}$ Cracow University of Technology, Kraków, Poland; Institute of Chemistry and Inorganic Technology; ${ }^{2}$ AGH University of Science and Technology, Kraków, Poland; 3The Mineral and Energy Economy Research Institute of the Polish Academy of Sciences, Kraków, Poland

\begin{abstract}
The rebuilding of the phosphorus cycle can be performed with the use of both biotechnology and chemical technology. This paper presents a review of the phosphorus cycle and the different approaches that can be taken to the recovery of phosphorus from phosphaterich waste. Critical issues in the phosphorus cycle are also discussed. Methods for the recovery of phosphorus form sewage sludge ash are widely explored and divided into two groups: wet extraction methods and thermochemical methods. Laboratory-scale methods are described, as well as proposed industrial technologies, with particular regard to the possibilities for their implementation in Poland. Phosphorus recovery methods from SSA (sewage sludge ash) in our country seems to be promising due to the increasing number of sewage sludge incineration plants, which could easily supply ash to future recovery installations. For the effective recovery of $P$ from sewage sludge ash, it is essential to make the right choice in determining the appropriate method to use with respect to the particular properties of the ash composition available. A patented method of phosphorus recovery by acid extraction methods, developed by Cracow University of Technology, results in an efficiency of $80-96 \%$ for phosphorus recovery. 3000 to 4000 tons of phosphorus per year can be recycled and introduced back into the environment, that covers around $7 \%$ of the total amount of phosphorus ore imported into Poland between 2008 and 2009.
\end{abstract}

Key words: phosphorus cycle, phosphorus recovery, sewage sludge ash, acidic extraction of phosphorus, sewage sludge incineration

Received: 15 October, 2013; revised: 04 December, 2013; accepted: 12 December, 2013, available on-line: 29 December, 2013

\section{INTRODUCTION}

The reports all over the world unanimously state that further global development will be dependent on the restoration of equilibrium between economic progress and the protection of natural resources (Morseet al., 1993; Jasinski, 2010). Phosphorus is an essential element of life and is fundamental to the modern agricultural system. The importance of this element in affecting ecological dynamics comes not only from its predominance in cells but also from its relative abundance in the environment (Blank, 2012). P is considered a potentially critical resource because its reserves are limited. Phosphorus limitation often arises because much soil-based $\mathrm{P}$ is actually unavailable to most plant life. According to Li \& Brett (2013), analysis of Soluble Reactive Phosphorus (SRP) showed that it provides a poor index of dissolved phosphorus bioavailability in natural systems.
Within 21 inorganic and organic phosphorous-containing compounds, $81 \%$ did not fit the classic assumption that SRP approximately equals bioavailable P. From inorganic compounds, all of the $\mathrm{P}$ that was bioavailable for algal growth was only in the form of $\mathrm{CaHPO}_{4}$.

Phosphorus compounds are mostly used in modern agriculture for both crop farming and animal husbandry. From a total production of $24.87 \mathrm{Mt}$ of phosphorus, fertilizers accounted for $82 \%$ of the total phosphate rock consumption in 2012 (Scholz et al., 2013; Scholz \& Wellmer, 2013). The main reserves of phosphate rock are found in relatively few countries. $65 \%$ of global raw material production belonged to 3 countries: China, United States and Marocco \& Western Sahara (IFDC, 2010; Jasinski, 2012). Annually, Poland imports approximately 460000 tons (2008) of raw phosphorus material in the form of concentrates, mainly from Morocco, Tunisia and Syria (GSMiE PAN, 2011). The current state of global $\mathrm{P}$ reserves and resources is extremely complex and depends heavily on the cost-efficiency of the mining and extraction processes used. According to forecasts, world phosphorite and apatite reserves will become exhausted during the next 60-400 years, depending on a potential trend in the phosphate industry moving increasingly towards improved recovery rates and the mining of lowergrade phosphate rock (Heffer et al., 2006; IFDC, 2010; Jasinski, 2012).

A critical issue in the phosphorus cycle is the low efficiency and losses associated with the production and use of phosphate fertilizers. Only about $10 \%$ of mined phosphorus is currently consumed, according to Cordell et al. (2009). The two largest causes of P loss globally have been identified as erosion and runoff of mined $\mathrm{P}$ (estimated at $46 \%$ ) and animal waste (40\%). Nearly all of the $\mathrm{P}$ consumed by humans is transported as sewage to municipal wastewater treatment plants. About one-half of that phosphorus is discharged after treatment and directly enters waterways, increasing eutrophication $(8 \%$ of mined P), while the majority of the remainder $(7 \%$ of mined P) is disposed of in landfills as sludge (Rittmann et al., 2011; Liu et al., 2008; Cordell et al., 2009; Schröder et al., 2010; Clift \& Show, 2012). Therefore the impending scarcity of phosphorus in the coming centuries is not a physical problem, but economic, technical and political one.

Phosphorus sustainability is defined as a two-sided challenge: pollution on the one hand, scarcity on the other. This predicament creates a broad field of oppor-

e-mail: gorazda@chemia.pk.edu.pl

*Presented at: 5 th Central European Congress of Life Sciences EUROBIOTECH 2013 
tunity, calling for the improvement of technologies and practices that 'complete the phosphorus cycle'. The key areas for action according to the European Union are the balancing of consumption, improving the processing and utilization of phosphorus, the recycling and reuse of phosphorus from sewage sludge and bio-waste and reducing organic phosphorus losses in the food chain. EU recommendations were echoed in the activities of the European fertilizer industry, which intends to replace natural phosphorus materials in phosphorus-rich waste (Schroderet al., 2009; EEA, 2011).

\section{POSSIBILITIES FOR REPAIRING THE PHOSPHORUS CYCLE}

The rebuilding of the phosphorus cycle can be performed with the use of both biotechnology and chemical technology. Aspects of biotechnology reviewed by Blank (2012) include phosphate solubilisation (from the soil), phosphate recovery and uptake, phosphate storage, and phosphate mobilisation. Enhanced biological phosphorus removal (EBPR) reactors with phosphate-recovery technologies in combination with low pressure wet oxidation and nanofiltration to recover phosphate as diluted phosphoric acid or phosphate-based fertiliser should be mentioned (Yan et al., 2013, Raj et al., 2013, Blöcher et al., 2012, Wong et al., 2013). As an example, a full-scale EBPR plant operating in Fukuyama City, Japan recovered phosphorus in the form of calcium phosphate using an additional step of heating the sludge, followed by clarification and $\mathrm{CaCl}$ precipitation (Blank, 2012). Other examples are the use of microbes for phosphate mobilisation in soil to improve phosphate efficiency on fertilized fields, the development of crop variants with altered root morphology enabling improved $\mathrm{P}$ acquisition and the use of Phytate as an alternate P source (Tian et al., 2012; Adeola \& Cowieson, 2011; Ridoutt et al., 2013).

Chemical technology is useful for recovery of phosphorus from waste water streams (Bradford-Hartke et al., 2012; Petzet et al., 2012; Sengupta et al., 2011; Kodera et al., 2013), sewage sludge (Sano et al., 2012), animal waste (Schröder \& Verloop, 2010), industrial waste and other industrial emissions (Hutnik et al., 2013; Gorazda et al., 2010).

Sewage sludge - waste containing phosphorus compounds concentrated at cellular matter or in the form of insoluble phosphates, after thermal processing could potentially be used as a source of concentrated phosphorus and as a substitute for natural ore. In the EU, 10-21\% of the whole amount of sewage sludge is incinerated, constituting nearly 0.6 million tons of sewage sludge ash (SSA) per year and this amount will continue to increase. Incineration procedures have undergone significant improvements during the last few years, mainly in the areas of technology, cost reduction and environmental protection. However, topics such as the cost of treatment of flue gases and ashes (Nowak et al., 2012), dioxin and furan emission (Tyagi \& Lo, 2013), the release of heavy metals (Nzihou et al., 2013; Li et al., 2012) and the handling of solid residues are all still of significant importance to thermal processes (Fytili et al., 2008). According to forecasts, Old Member States will continue to lead on these technologies and probably by 2020 , thermal treatment with energy recovery could make up $37 \%$, more than double compared to EU-12.

Although Poland is the greatest sludge producer (regarding EU-12 countries, $42 \%$ of total sludge amounts is produced in Poland), thermal methods of sewage sludge utilisation have not been very popular in recent years (Kelessidis et al., 2012). Nowadays, a different tendency is observed, due to the EU regulation implemented on $1^{\text {st }}$ January 2013, banning deposition of this waste in landfills. Presently, 11 incineration plants are operating in our country, bringing about a significant reduction in the volume of sewage sludge and resulting in full stability and biological safety of this waste (Table 1). Phosphorus concentration in the ash can be compared to the poorest natural raw phosphate materials with average $\mathrm{P}$ concentration in European ashes being around 7\%. Table 2 shows the content of selected elements in SSA from 25 different European and 6 Polish sewage sludge incineration plants.

For the utilization of SSA as a potential source of phosphorus, several parameters of the ash have to be taken into consideration. It is also important to choose the most appropriate recovery method. The chemical composition of the ash depends on the treatment method (either biological or chemical) that is used in wastewater treatment plants. The type of precipitant agent used is also significant: iron or aluminium salts that are used for phosphorus compound precipitation cause a higher concentration of $\mathrm{Fe}$ or $\mathrm{Al}$ respectively. It is also possible to observe a high concentration of iron in the ash that originates from the biological treatment due to a significant amount of this element present in the water in certain regions. The presence of heavy metals (HM) like lead, zinc, cadmium and nickel in the ash disqualify this waste from direct usage as fertilizer (despite a

Table 1. Characteristic of the Polish mono-incineration plants (technological data from each plant, 2012)

\begin{tabular}{|c|c|c|c|c|}
\hline Location & Starting year & $\begin{array}{l}\text { Quantity of incinerated sewage sludge } \\
\text { (T d.S./Day) }\end{array}$ & Technology & $\begin{array}{l}\text { Ash production } \\
\text { (T/day) }\end{array}$ \\
\hline Gdynia & 1997 & 25 & Fluidised bed & 10 \\
\hline Łódź & 2010 & 46 & 2 Fluidised bed Pyrofluid R-43 & 15 \\
\hline Kielce & 2011 & 19 & Fluidised bed & 3.1 \\
\hline Bydgoszcz & 2012 & 19 & Fluidised bed & 2.3 \\
\hline Kraków & 2011 & 55 & Fluidised bed Pyrofluid & 19.5 \\
\hline Warszawa & 2013 & $\begin{array}{l}\text { Max. } \\
613\end{array}$ & Fluidised bed Pyrofluid R-67 & 73 \\
\hline Szczecin & 2010 & 40 & Grate furnace & 12 \\
\hline
\end{tabular}


Table 2. Content of selected elements in Polish and European Sewage Sludge Ash (SSA) (Donatello et al., 2010; Franz, 2008; Stark et al., 2006; Lapa et al., 2007; Adam et al., 2009)

\begin{tabular}{|c|c|c|c|c|c|c|c|}
\hline & & $\begin{array}{c}P \\
(\%)\end{array}$ & $\begin{array}{l}\mathrm{Fe} \\
(\%)\end{array}$ & $\begin{array}{c}\mathrm{Cd} \\
(\mathrm{mg} / \mathrm{kg})\end{array}$ & $\begin{array}{c}\mathrm{Ni} \\
(\mathrm{mg} / \mathrm{kg})\end{array}$ & $\begin{array}{c}\mathrm{Cu} \\
(\mathrm{mg} / \mathrm{kg})\end{array}$ & $\begin{array}{c}\mathrm{Zn} \\
(\mathrm{mg} / \mathrm{kg})\end{array}$ \\
\hline \multirow{3}{*}{$\begin{array}{l}\text { SSA } \\
\text { from } 25 \text { European incineration plants }\end{array}$} & Min & 3.6 & 1.5 & 0 & 40 & 417 & 910 \\
\hline & Max & 11.2 & 17.0 & 14 & 621 & 2,483 & 46000 \\
\hline & Average & 7.3 & 8.8 & 5 & 121 & 956 & 921 \\
\hline \multirow{3}{*}{$\begin{array}{l}\text { SSA } \\
\text { from } 6 \text { Polish incineration plants }\end{array}$} & Min & 8.7 & 3.8 & 4 & 59 & 483 & 799 \\
\hline & Max & 11.2 & 11.3 & 71 & 300 & 979 & 7200 \\
\hline & Average & 10.1 & 8.1 & 25.2 & 139.8 & 758 & 3903 \\
\hline
\end{tabular}

high phosphorus concentration). Recovery methods have to take into account a significant amount of these elements in the ash while HM removal seems to be an absolute prerequisite in considerations regarding methods of phosphorus recovery from SSA.

The characteristics of the ash differ according to the type of thermal utilization employed. The most popular method is incineration in a fluidized bed, which is considered to be the best available technique (BAT) for sewage sludge disposal and is also implemented in Poland (Table 1). The main drawback of this method is the relatively low incineration temperature usually used in fluidized bed furnaces. It is often $850^{\circ} \mathrm{C}$ that is the temperature high enough to achieve total stabilization of the waste and to remove pathogens and organic compounds. However, it is also at this temperature that iron present in the sludge occurs in the form of calcium-iron phosphate, which causes handling problems during extraction and recovery processes. It has been proven that at a temperature of $950^{\circ} \mathrm{C}$, iron contained in the ash is converted into a hematite form, which is insoluble in mineral acids. As a result, it is possible to recover phosphorus selectively (Gorazda et al., 2012). Additional treatment options have to be taken into consideration in the case of sewage sludge ash containing iron that will be in soluble form during extraction process.

\section{METHODS OF PHOSPHORUS RECOVERY FROM SEWAGE SLUDGE ASH}

Essentially, the methods of phosphorus recovery from SSA can be divided into two groups: wet extraction methods and thermochemical methods.

The principle behind the wet extraction method is the leaching of sewage sludge ash with acids or bases. The efficiency of the process depends on; the type and concentration of the extractant, the $\mathrm{pH}$ value, the extraction time and the incineration temperature of sewage sludge. The extraction methods could be divided into following groups:

- Acidic leaching with $\mathrm{H}_{2} \mathrm{SO}_{4}$ (Donatello et al., 2010; Franz, 2008; Tan \& Lagerkvist, 2011; Biswas et al., 2009; Dittrich et al., 2009), HCl (Donatello et al., 2010; Tan \& Lagerkvist, 2011; Biswas et al., 2009; Dittrich et al., 2009; Schaum et al., 2013), $\mathrm{HNO}_{3}$ (Tan \& Lagerkvist, 2011; Biswas et al., 2009; Gorazda et al., 2012), $\mathrm{H}_{3} \mathrm{PO}_{4}$ (Dittrich et al., 2009; Gorazda et al., 2012), citric and oxalic acid (Biswas et al., 2009);

- Basic leaching with $\mathrm{NaOH}$ (Biswas et al., 2009; Dittrich et al., 2009; Schaum et al., 2013; Stark et al., 2006);
- Bioextraction with acidithiobacillus ferrooxidans bacteria (Tan \& Lagerkvist, 2011);

- Supercritical fluid extraction or wet oxidation of ashes from supercritical water oxidation (Stark et al., 2006; Tyagi \& Lo, 2013).

Significant quantities of heavy metals in the ash require an additional treatment step. It is possible to remove HM via the precipitation method (metals removed in the form of sulphides), liquid-liquid extraction, ionexchange, as well as nanofiltration (Donatello et al., 2010). The most popular extractants are sulphuric acid and hydrochloric acid due to their relatively low price and a high recovery level of up to $99 \% \mathrm{P}$ (Donatello et al., 2010; Franz M, 2008; Biswas et al., 2009). Nevertheless, during the process some problematic by-products are formed: gypsum or $\mathrm{CaCl}_{2}$. Other studies have shown that leaching efficiency drops to $30 \%$ in the case of a base being used as an extractant (Dittrich et al., 2009).

The second group of methods of phosphorus recovery from SSA is the thermochemical treatment of ash. In this process sewage sludge ash is mixed with a chloride donor and subsequently heated within a temperature range of $900-1050^{\circ} \mathrm{C}$, leading to the transformation of phosphate compounds into a bioavailable form. Meanwhile, heavy metals present in the ash react with the chloride donor resulting in the formation of volatile chlorides, which evaporate and hence the heavy metalfree ash is obtained. The investigations proved that the HM removal efficacy is related to the chloride donor type, the temperature of the process, the reaction time, the reactor type and the form of the ash eg. pellets or briquettes (Nowak et al., 2012; Mattenberger et al., 2010).

It is also possible to classify metallurgic methods into the thermochemical group. The ash is used as a substitute for raw phosphate rock present in the conventional technologies of phosphorus production (Schipper et al., 2001).

Table 3 summarizes the characteristics of the extraction and thermochemical methods, which have recently been studied in Europe.

The technologies for recovery from ash must take into account the industrial procedures of sewage treatment plants in Poland, where the maximum phosphorus content in the treated wastewater is related to the use of biological or chemical methods of phosphorus removal with iron or aluminium salts. The significant amount of iron present in Polish ash disqualifies it from its possible utilisation in the thermochemical methods (iron does not form volatile chlorides) and also in the metallurgical method, where the maximum acceptable iron concentration must not exceed 1\% according to Mattenberger et al. (2010). Thus the proper means of SSA disposal would 
Table 3. A comparison of recovery methods of phosphorus from sewage sludge ash

\begin{tabular}{|c|c|c|c|c|}
\hline \multicolumn{2}{|c|}{ Method name } & \multirow{2}{*}{$\begin{array}{l}\text { Scale } \\
\text { Lab. }\end{array}$} & \multirow{2}{*}{$\begin{array}{l}\text { Principles } \\
\text { SSA leaching with } \mathrm{H}_{2} \mathrm{SO}_{4} \text { added up to } \mathrm{pH} \text { value } 1.5 \text {. Neu- } \\
\text { tralization of the system with } \mathrm{NaOH}(\mathrm{pH}=3.5) \text { and } \mathrm{AlPO}_{4} \\
\text { precipitation. } \\
\text { Advanced method: dissolution of } \mathrm{AlPO}_{4} \text { in } \mathrm{NaOH} \text { and he- } \\
\text { avy metals separation. }\end{array}$} & \multirow{2}{*}{$\begin{array}{l}\begin{array}{l}\text { Obtained } \\
\text { product }\end{array} \\
\\
\mathrm{AlPO}_{4} / \\
\mathrm{Ca}_{3}\left(\mathrm{PO}_{4}\right)_{2}\end{array}$} \\
\hline \multirow{7}{*}{ 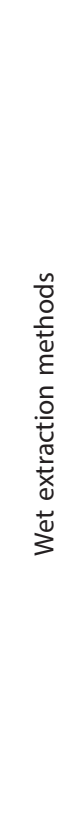 } & $\begin{array}{l}\text { SEPHOS/ Advanced SEPHOS } \\
\text { (Schaum et al., 2013) }\end{array}$ & & & \\
\hline & $\begin{array}{l}\text { PASH } \\
\text { (Dittrich et al., 2009) }\end{array}$ & Pilot & $\begin{array}{l}\text { SSA leaching with } 8 \% \mathrm{HCl} \text {, liquid-liquid extraction using } \\
\left.\text { tri- }\left(\mathrm{C}_{8} \mathrm{C}_{10}\right) \text {-alkilamine (Alamine }{ }^{\circledR} 336\right) \text { and tri-n-butyl pho- } \\
\text { sphate (TBP) to obtain high phosphorus against iron reco- } \\
\text { very selectivity. Final step: phosphates precipitation. }\end{array}$ & $\begin{array}{l}\text { Magnesium or } \\
\text { calcium phos- } \\
\text { phate/MAP }\end{array}$ \\
\hline & $\begin{array}{l}\text { BIOCON } \\
\text { (Donatello et al., 2010) }\end{array}$ & Pilot & $\begin{array}{l}\text { SSA leaching with sulphuric acid. The step of treating } \\
\text { extract on ion exchange columns. }\end{array}$ & $\mathrm{H}_{3} \mathrm{PO}_{4}$ \\
\hline & $\begin{array}{l}\text { AquaReci } \\
\text { (Stark et al., 2006) }\end{array}$ & Pilot & $\begin{array}{l}\text { SSA from supercritical water oxidation process }\left(374^{\circ} \mathrm{C}, 220\right. \\
\text { bar), subsequently leaching with base. Phosphate com- } \\
\text { pounds precipitation with lime milk. }\end{array}$ & $\begin{array}{l}\text { Calcium phos- } \\
\text { phate }\end{array}$ \\
\hline & $\begin{array}{l}\text { SESAL-Phos } \\
\text { (Petzet et al., 2012) }\end{array}$ & Lab. & $\begin{array}{l}\text { Acidic leaching due to phosphorus transformation into } \\
\text { Al-P form, afterwards precipitate dissolution in basic } \\
\text { extractant, selectively among HM. Phosphorus compounds } \\
\text { obtained via } \mathrm{CaO} \text { addition. }\end{array}$ & $\begin{array}{l}\text { Calcium phos- } \\
\text { phate }\end{array}$ \\
\hline & $\begin{array}{l}\text { Zero sludge discharge tech- } \\
\text { nology } \\
\text { (SPIRIT 21, 2007) }\end{array}$ & Project & $\begin{array}{l}\text { SSA basic leaching with } \mathrm{KOH} \text { or } \mathrm{NaOH} \text {, an intermediate for } \\
\text { liquid fertilizers is obtained. Final step: precipitation with } \\
\text { lime milk. }\end{array}$ & $\begin{array}{l}\text { liquid } \mathrm{K}_{3} \mathrm{PO}_{4} / \\
\text { calcium pho- } \\
\text { sphate }\end{array}$ \\
\hline & $\begin{array}{l}\text { ECOPHOS (PL) } \\
\text { (Gorazda et al., 2012) }\end{array}$ & Micro-technical & $\begin{array}{l}\text { Thermic pre-treatment of the ash at } 950^{\circ} \mathrm{C} \text { (iron trans- } \\
\text { ferred into hematite form that is insoluble in acids), acidic } \\
\text { leaching with } \mathrm{HNO}_{3} \text { or } \mathrm{H}_{3} \mathrm{PO}_{4} \text {, phosphate precipitation } \\
\text { with } \mathrm{CaO} \text {. }\end{array}$ & $\begin{array}{l}\text { Calcium phos- } \\
\text { phate }\end{array}$ \\
\hline \multirow{3}{*}{ 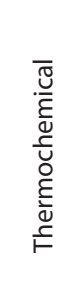 } & $\begin{array}{l}\text { AshDEC } \\
\text { (Nowak et al., 2012) }\end{array}$ & Pilot & $\begin{array}{l}\text { Thermochemical treatment of the ash mixed with } \mathrm{MgCl}_{2} \\
\text { or } \mathrm{CaCl}_{2} \text { at } 1000^{\circ} \mathrm{C} \text {, volatile chlorides formation, transforma- } \\
\text { tion of the phosphorus compounds into bioavailable form. }\end{array}$ & $\begin{array}{l}\text { Ash as ferti- } \\
\text { lizer }\end{array}$ \\
\hline & $\begin{array}{l}\text { Mephrec } \\
\text { (Nieminen, 2010) }\end{array}$ & Pilot & $\begin{array}{l}\text { SSA briquettes sintering in a shaft furnace with dolomite } \\
\text { and lime as a fluxing material and coke as a reducer and } \\
\text { an energy carrier. Temperature of the process: } 2000^{\circ} \mathrm{C} \text {, } \\
\text { silica phosphate from metals separation at } 1450^{\circ} \mathrm{C}\end{array}$ & $\begin{array}{l}\text { Ash with high } \\
\text { calcium and } \\
\text { phosphorus } \\
\text { concentration }\end{array}$ \\
\hline & $\begin{array}{l}\text { Termphos } \\
\text { (Schipper et al., 2001) }\end{array}$ & Industrial & $\begin{array}{l}\text { SSA used as a raw phosphate rock substitute. } \mathrm{P}_{4} \text { is pro- } \\
\text { duced in an electric furnace at } 1500^{\circ} \mathrm{C} \text {. }\end{array}$ & $\mathrm{P}_{4} / \mathrm{FePO}_{4}$ \\
\hline
\end{tabular}

be iron immobilization while carrying-out the wet extraction process with acidic extractants, which is in fact the goal of the Ecophos project being conducted at Cracow University of Technology, in accordance with patented technological solutions (Gorazda et al., 2010; Gorazda et al., 2012). Phosphoric and nitric acid usage will minimize the generation of undesirable waste. The proposed solution can be used industrially for the production of chemical phosphate fertilizers and can be used in the construction industry as well as for municipal waste minimization technology through the beneficial recycling of phosphorus.

\section{CONCLUSIONS}

Rebuilding the global and local phosphorus cycles will only be possible with the use of sustainable development rules and adequate phosphate-rich waste management. Sewage Sludge Ash is a concentrated source of phosphorus and can be successfully recycled via a number of different routes. Unfortunately there are only a handful of industrial scale examples of such recycling currently in existence, which does not encourage its wide-scale adoption. It is however likely that the technologies that have been presented here will become more attractive as both phosphate prices and ash disposal costs continue to rise. Sewage sludge ash generated by Polish incineration plants tend to contain considerable amounts of phosphorus, but the significant amount of iron present in the ash eliminates the possibility for its utilisation in thermochemical methods. A patented method of phosphorus recovery by acid extraction methods, developed by Cracow University of Technology, results in an efficiency of $80-96 \%$ for phosphorus recovery (Gorazda et al., 2012; Gorazda \& Wzorek, 2006). The amount of waste generated from the thermal treatment of sewage sludge in eight Polish incineration plants is approximately 43000 tons per year. The average phosphorus content in Polish ash is around $9.7 \%$, though 3000 to 4000 tons of phosphorus per year can be recycled and introduced back into the environment. That amount is equivalent to 30770 tons of phosphorus ore with an average phosphorus content level of 13\% (Morocco, Tunisia phosphates) and covers around $7 \%$ of the total amount of phosphorus ore imported into Poland between 2008 and 2009. According to forecasts for Poland, in 2020 about 95000 tons of dry mass of sewage sludge will be utilised thermally, which will undoubtedly increase the potential for phosphorus recycling (GUS, 2012).

Moreover, analytics for the European Union and the Polish Market clearly indicate that growing demand for phosphate fertilizers worldwide is expected and the establishment of export duties will be a significant obstacle to furthering the development of existing technology based on phosphate fertilizers and compound fertilizers (Technological Foresight, 2011). From published reports, it is also clear that to ensure food security in Poland, all the basic mineral fertilizers must be produced in our 
country. Developing technologies that take into account local conditions and that result in fertilizer production is fundamental. Even more important than this is to establish the possibilities for obtaining cheaper or alternative sources of phosphorus for individual industries.

\section{Acknowledgements}

This study was supported by NCBiR through the research grant PBS1/A1/3/2012.

\section{REFERENCES}

Adam C, Peplinski B, Michaelis M, Kley G, Simon F (2009) Termochemical treatment of sewage sludge ashes for phosphorus recovery. Waste Manage 29: 1122-1128.

Adeola O, Cowieson AJ (2011) Opportunities and challenges in using exogenous enzymes to improve nonruminant animal production. $J$ Anim Sci 89: 3189-3218.

Biswas BK, Inoue K, Harada H, Ohto K, Kawakita H (2009) Leaching of phosphorus from incinerated sewage sludge ash by means of acid extraction followed by adsorption on orange waste gel. $J$ Environ Sc 21: 753-1760.

Blank LM (2012)The cell and P: from cellular function to biotechnological application. Curr Opin Biotechnol 23: 846-851.

Blöcher C, Niewersch C, Melin T (2012) Phosphorus recovery from sewage sludge with a hybrid process of low pressure wet oxidation and nanofiltration. Water Res 46: 2009-2019.

Bradford-Hartke Z, Lant P, Leslie G (2012). Phosphorus recovery from centralised municipal water recycling plants. Chem Eng Res Des 90: $78-85$.

Clift R, Shaw H (2012) An Industrial Ecology Approach to the Use of Phosphorus. Proc Eng 46: 39-44.

Cordell D, Drangert JO, White S (2009) The story of phosphorus: global food security and food for thought. Glob Environ Chang 19: 292-305.

Dittrich C, Rath W, Montag D, Pinnekamp J (2009) Phosphorus recovery from sewage sludge ash by a wet-chemical process, In: International Conference on Nutrient Recovery from Wastewater Streams, IWA Publishing, London, England.

Donatello S, Tong D, Cheeseman C R (2010) Production of technical grade phosphoric acid from incinerator sewage sludge ash (ISSA). Waste Manage 30: 1634-1642.

EEA - European Environment Agency (2011) "Resource efficiency in Europe - Policies and approaches in 31 EEA member and cooperating countries", EEA Report n5/2011, October 2011.

Elser JJ (2012) Phosphorus: a limiting nutrient for humanity? Curr Opin Biotechnol 23: 833-838.

Franz M (2008) Phosphate fertilizer from sewage sludge ash (SSA). $W$ aste Manage 28: 1809-1818.

Fytili D, Zabaniotou A, (2008) Utilization of sewage sludge in EU application of old and new methods: a review. Renew Sustain Energy Rev 12: $116-140$.

GSMiE PAN (2011). Bilans Gospodarki Surowcami Mineralnymi Polski i Świata, Wydawnictwo: Instytutu GSMiE PAN Kraków 2011.

Gorazda K, Kowalski Z, Wzorek Z (2010) phosphorus recovery from industrial waste, PL Patent No. 207457.

Gorazda K, Kowalski Z, Wzorek Z (2012) From sewage sludge ash to calcium phosphate fertilizers. Pol J Chem Technol 14: 54-58.

Gorazda K, Jodko M, Kowalski Z, Wzorek Z (2010) PL Patent No. 207630 B1, Republic of Poland Patent and Trademark Office.

Gorazda K, Jodko M, Kowalski Z, Wzorek Z (2012) PL Patent No. 210459 B1, Republic of Poland Patent and Trademark Office.

Gorazda K, Wzorek Z (2006) Selection of leaching agent for phosphorus compounds extraction from the sewage sludge ash. Pol J Chem Technol 8: 15-18.

GUS (2012) Main Statistical Office, Environmental Protection, Warszawa 2012.

Heffer P, Prud'homme M, Muirhead B, Isherwood K (2006). Phosphorus fertilisation: issues and outlook. Proceedings International Fertiliser Society 586. 30 pp. York, UK,

Hutnik N, Kozik A, Mazienczuk A, Piotrowski K. Wierzbowska B, Matynia A (2013) Phosphates (V) recovery from phosphorus mineral fertilizers industry wastewater by continuous struvite reaction crystallization process.W ater Res 47: 3635-3643.

IFDC (2010) Sufficient phosphate rock resources Available for years. International Fertilizer Development Center, Muscle Shoals, AL 35662, USA. Report 35: 1 .

Jasinski SM (2010) Phosphate Rock In: Mineral Commodity Summaries, U.S. Geological Survey, United States Government Printing Office, Washington.

Jasinski SM (2012). Phosphate rock. In: US Geological Survey, editor. Mineral commodity summaries. pp 118-119. USGS.
Kelessidis A, Stasinakis AS (2012) Comparative study of the methods used for treatment and final disposal of sewage sludge in European countries. Waste Manage 32: 1186-1195.

Kodera H, Hatamoto M, Abe K, Kindaichi T, Ozaki N, Ohashi A (2013) Phosphate recovery as concentrated solution from treated wastewater by a PAO-enriched biofilm reactor. Water Res 47: 20252032.

Lapa N, Barbosa R, Mendes B, Abelha P, Gulyurtlu I, Oliveira S (2007) Chemical and ecotoxicological characterization of ashes obtained from sewage sludge combustion in a fluidised-bed reactor. $J$ Hazard Mater 147: 175-183.

Li B, Brett MT( 2013) The influence of dissolved phosphorus molecular form on recalcitrance and bioavailability. Environ Pollut 182: 37-44.

Mattenberger H, Fraissler G, Jöller M, Brunner T, Obernberger I, Herk P, Hermann L (2010) Sewage sludge ash to phosphorus fertilizer (II): Influences of ash and granulate type on heavy metal removal. Waste Manage 30: 1622-1633.

Morse GK, Lester JN, Perry R (1993) The economic and environmental impact of phosphorus removal from wastewater in the European Community. Selpher Publications, London, 1993.

Nieminen J (2010). Phosphorus recovery and recycling from municipal wastewater sludge. A Master of Sciences dissertation. Aalto University School of Science and Technology, Aalto, Finland.

Nzihou A, Stanmore B (2013) The fate of heavy metals during combustion and gasification of contaminated biomass - A brief review. J Hazard Mater 256: 56-66.

Nowak B, Rocha SF, Aschenbrenner H, Winter F (2012) Heavy metal removal from MSW fly ash by means of chlorination and thermal treatment: Influence of the chloride type. Chem Eng J 179: 178-185.

Petzet S, Cornel P (2012). Prevention of struvite scaling in digesters combined with phosphorus removal and recovery- the FIX-Phos process. Water Environ Res 84: 220-226.

Petzet S, Peplinski B, Cornel P (2012) On wet chemical phosphorus recovery from sewage sludge ash by acid or alkaline leaching and an optimized combination of both. Water Res 46: 3769-3780.

Raj SE, Banu PJ, Kaliappan S, Yeom IT, Kumar AS (2013) effects of side-stream, low temperature phosphorus recovery on the performance of anaerobic/anoxic/oxic systems integrated with sludge pretreatment. Bioresour Technol 140: 376-384.

Ridoutt GB, Wand E, Sanguansri P, Luo Z (2013) Life cycle assessment of phosphorus use efficient wheat grown in Australia. Agric Sys 120: 2-9.

Rittmann BE, Mayer B, Westerhoff P, Edwards M (2011) Capturing the lost phosphorus. Chemosphere 84: 846-853.

Sano A, Kanomata M, Inoue H, Sugiura N, Xu KQ, Inamori Y (2012) Extraction of raw sewage sludge containing iron phosphate for phosphorus recovery. Chemosphere 89: 1243-1247.

Sengupta S, Pandit A (2011) Selective removal of phosphorus from wastewater combined with its recovery as a solid-phase fertilizer. Water Res 45: 3318-3330.

Schaum C, Cornel P, Norbert J (2013) Phosphorus Recovery from Sewage Sludge Ash - A Wet Chemical Approach. Retrieved 11 March, 2013, from: http://www.bvsde.paho.org/bvsaar/cdlodos/pdf/phosphorusrecovery583.pdf.

Schipper WJ, Klapwijk A, Potjer B, Rulkens WH, Temmink BG, Kiestra FDG, Lijmbach ACM (2001) Phosphate recycling in the phosphorus industry. Environ Technol 22:1337--1345.

Scholz RW, Ulrich AE, Eilittä M, Roy A (2013) Sustainable use of phosphorus: A finite resource. Sci Total Environ 461: 799-803.

Scholz RW, Wellmer FW (2013) Approaching a dynamic view on the availability of mineral resources: what we may learn from the case of phosphorus? Glob Environ Chang 23: 11-27.

Schroder JJ, Cordell D, Smit AL, Rosemarin A. (2009) Sustainable use of phosphorus, European Union tender project ENV.B.1/ ETU/2009/0025). Report 357, Plant Research International, Wageningen University and Research Centre. 122 pp. Wageningen, The Netherlands.

Schröder JJ, Verloop J (2010). Slurry separation could allow a wider use of manure within the EU Nitrates Directive. In: Proceedings Ramiran 2010 Conference, Cordovil C, Ferreira L, eds. Lisboa, Portugal, Lissabona.

SPIRIT21 (2007) Sewege Technology Development Project (LOTUS Project), (2007). Zero Sludge Discharge Technology, Technology Evaluation concerning Phosphorus Recovery from Sewage Sludge Incinerator Ash, from: http://nett21.gec.jp/rerss/reports/rp02.pdf.

Stark K, Plaza E, Hultman B (2006) Phosphorus release from ash, dried sludge and sludge residue from supercritical water oxidation by acid or base. Chemosphere 62: 827-832.

Steen I (1988) Phosphorus availability in the 21st century: Management of a non-renewable resources. Phosphorus and Potassium 217: 25-31.

Tan Z, Lagerkvist A (2011). Phosphorus recovery from the biomass ash. A review. Renew Sust Energ Rev 15: 3588-3602.

Tian J, Wang X, Tong Y, Chen X, Liao H (2012) Bioengineering and management for efficient phosphorus utilization in crops and pastures. Curr Opin Biotechnol 23: 866-871. 
Technological Foresight (2011) Scenariusze i rekomendacje, grudzień 2011 http://www.inorganicwaste.eu/.

Tyagi VK, Lo SL (2013) Sludge: A waste or renewable source for energy and resources recovery?. Renew Sustain Energy Rev 25: 708-728.

Wong PY, Cheng KY, Kaksonen AH, Sutton DC, Ginige MP (2013) A novel post denitrification configuration for phosphorus recovery using polyphosphate accumulating organisms, Water Res http://dx. doi.org/10.1016/j.watres.2013.08.023 (in press).

Yan P, Ji F, Wang FJ, Guan W, Chen Q (2013) Pilot-scale test of an advanced, integrated wastewater treatment process with sludge reduction, inorganic solids separation, phosphorus recovery, and enhanced nutrient removal (SIPER). Bioresour Technol 142: 483-489. 